\title{
1 Insights on the health benefits of the bioactive compounds of coffee silverskin
}

2 extract

3 Beatriz Fernandez-Gomez ${ }^{\text {a }}$, Adriana Lezama ${ }^{\text {a }}$, Miryam Amigo-Benavent ${ }^{\text {be }}$, Mónica

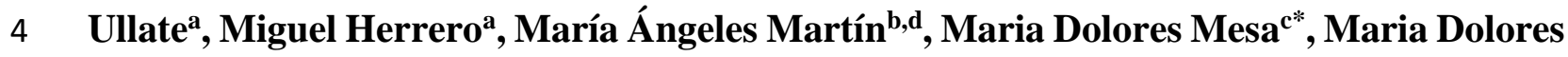
5 del Castilloa*.

6 a Department of Food Analysis and Bioactivity, Institute of Food Science Research (CIAL, CSIC7 UAM), 28049 Madrid, Spain.

$8{ }^{\mathrm{b}}$ Department of Nutrition and Metabolism, Institute of Food Science, Technology and Nutrition 9 (ICTAN-CSIC), 28040 Madrid, Spain.

10 "Institute of Nutrition and Food Technology "José Mataix", Biomedical Research Center 11 (CIBM), University of Granada, 18100 Granada, Spain. Instituto de Investigación Biosanitaria 12 (IBS) Granada, Spain.

${ }^{\mathrm{d}}$ Spanish Biomedical Research Centre in Diabetes and Associated Metabolic Disorders (CIBERDEM), 28029 Madrid, Spain.

${ }^{\mathrm{e}}$ Centre for Interventions in Inflammation, Infection and Immunity (4i), University of Limerick, 16 Limerick, Ireland.

*Corresponding authors:

Maria Dolores del Castillo, Department of Food Analysis and Bioactivity, Institute of Food Autónoma de Madrid, 28049, Madrid, Spain. 
23 Maria Dolores Mesa, Institute of Nutrition and Food Technology "José Mataix", Biomedical

24 Research Center (CIBM), University of Granada, Avd del Conocimiento s/n 18100 Granada,

25 Spain

26 E.mail address: mdmesa@ugr.es

27 Abbreviations: CGA, chlorogenic acid; CSE, coffee silverskin extract, HA, hippuric acid;

28 GPx, glutathione peroxidase; GR, glutathione reductase; GSH, reduced glutathione; STZ,

29 streptozotocin, NA, nicotinamide; TE, trolox equivalent; ROS, reactive oxygen species, TPC,

30 total phenolic compounds. 


\section{Abstract}

32 The bioaccessibility of chlorogenic acid (CGA) and caffeine in coffee silverskin extracts (CSE) and the contribution of these substances to the prophylactic effect of CSE on the pathogenesis of diabetes has not been reported. This study aimed to evaluate the bioaccessibility, bioavailability and bioactivity of CGA and caffeine alone and in CSE in the pancreas of rats treated with streptozotocin-nicotinamide (type 2 diabetes model). Metabolism of CGA and

37 caffeine started in the gastrointestinal tract due to changes of $\mathrm{pH}$ taking place during digestion. Their metabolites protected pancreatic cells against the risk of diabetes. This is the first in vivo study to demonstrate a specific chemo-protective effect of CSE in pancreatic tissue, and this effect may be associated with its antioxidant capacity. Daily administration of CSE, CGA or caffeine $35 \mathrm{~d}$ previous to the induction of diabetes significantly reduced $(\mathrm{p}<0.05)$ pancreatic oxidative stress and protein damage. 
56 Keywords: coffee silverskin, chlorogenic acid, caffeine, bioaccessibility, metabolism, 57 pancreas oxidative stress, Type 2 diabetes.

58 Chlorogenic acid (PubChem CID: 1794427)

59 Hippuric acid (PubChem CID: 464)

60 Caffeine (PubChem CID: 2519)

61 Paraxanthine (PubChem CID: 4687)

62 
According to the International Diabetes Federation (IDF), type 2 diabetes mellitus (T2DM) is one of the most frequent diseases in the world, with 387 million cases in 2014 (IDF, Diabetes Atlas Group, 2015). T2DM is a very complex and multifactorial metabolic disease characterized by insulin resistance and $\beta$ cell failure, leading to high blood glucose levels. Oxidative stress plays an important role in hyperglycaemia-induced pancreas injury as well as in the early events leading to the development of T2DM. Advanced glycation end-products (AGEs) increase reactive oxygen species (ROS) formation and impair antioxidant systems. Furthermore, the formation of some AGEs is induced per se under oxidative conditions (Nowotny, Jung, Höhn, Weber, \& Grune, 2015). There is also evidence that antiglycative agents in foods and medicine may reduce the risk of diabetes and treat the pathology (Uribarri et al., 2015).

Coffee silverskin (CS), the tegument of green coffee beans (outer layer), is the only by-product of the roasting process. Previous studies have proposed the use of coffee silverskin extracts (CSE) as a natural source of bioactive compounds, such as chlorogenic acid (CGA), caffeine, melanoidins and dietary fibre among others, with putative health benefits (del Castillo, Fernandez-Gomez, Martinez-Saez, Iriondo, \& Mesa, in press). Indeed, glucoregulatory properties have recently been ascribed to CSE by-products of roasting coffee ( del Castillo, Fernandez-Gomez, Ullate, \& Mesa, 2014). The antidiabetic effect of CSE has been initially associated with its capacity to inhibit the enzymatic activity of $\alpha$-glucosidase and lipase taking into account in vitro results ( del Castillo, Fernandez-Gomez, Ullate, \& Mesa,). 2014). CSE is also able to inhibit the formation of AGEs. The anti-AGEs capacity of CSE may be ascribed to CGA and other bioactive compounds composing the extract (Mesías et al., 2014). FernandezGomez et al. (2015) reported a novel antiglycoxidative mechanism of action of CGA. Moreover, CSE may protect pancreatic tissue in vitro against oxidative stress induced by the 
commonly-used diabetogenic agent streptozotocin (STZ) (Fernandez-Gomez et al., in press).

The antidiabetic mechanism of action of CSE in vivo should be elucidated and the present study provides some insights on that matter.

91

92

93

94

Healthy effects associated with foodlargely depend on the bioaccesibility and bioavailability of their bioactive components in the organism. CSE, like other food matrices, is a complex mixture of bioactive compounds. Nowadays, the bioaccessibility of CGA and caffeine composing CSE, and therefore, their true in-vivo potential are unknown. Moreover, the contribution of CGA and caffeine to the prophylactic effect of CSE on the pathogenesis of diabetes has not been reported. This study aimed to evaluate the bioaccessibility, bioavailability and bioactivity of CGA and caffeine alone and in CSE in the pancreas of rats treated with STZnicotinamide (NA), using phytochemomics (del Castillo, Martinez-Saez, Amigo-Benavent \& Silvan, 2013b). No data on that matter have been previously published. Although CSE and coffee brews present some similarities in chemical composition they are significant different. As a consequence, the effect in health of both matrices may be very different. On the other hand, the valorisation of the coffee by-product into an antidiabetic product is of great interest and it has not been previously reported by others. The present study provides relevant data to support the interest of CSE as a functional product for diabetes and the potential of the coffee sector in bioeconomy.

\section{Material and Methods}

\subsection{Chemicals}

Pancreatin (P-1625), $\alpha$-amilase from human saliva type IX-A (A0521), 2.2'-azino-bis (3ethylbenzothiazoline-6-sulphonic acid) diammonium salt (ABTS), CGA, hippuric acid (HA), caffeine and paraxanthine solution, formic acid, o-phthaldehyde, 2,2'-Azobis (2amidinopropane) dihydrochloride (AAPH), glutathione reductase (GR), reduced and oxidized 
glutathione (GSH and GSSG, respectively), NADH, NADPH, tert-butylhydroperoxide (tBOOH), 1,4-dithiothreitol (DTT) buffer, STZ and NA were purchased from Sigma Chemical (Sigma-Aldrich, St Louis, MO, USA). The other chemicals and equipment used were: Pepsin (Merck 1.07190) and Amicon ${ }^{\circledR}$ Ultra-0.5 ml centrifugal filter unit fitted with an Ultracel ${ }^{\circledR}-10$ K regenerated cellulose membrane (30 kDa cut-off) (Merck, Darmstadt, Germany), Bradford reagent for the protein assay (Bio-Rad, München, Germany), methanol (MeOH) HPLC-grade (Lab-Scan, Gliwice, Sowinskiego, Poland). Distilled water was deionized using a Milli-Q system (Millipore, Bedford, MA, USA). All other chemicals were of analytical grade.

\subsection{Preparation of coffee silverskin extract}

Arabica CSE was prepared by aqueous extraction following the procedure patented by del Castillo et al. (2013a). Briefly, $50 \mathrm{ml}$ of boiling water was added to $2.5 \mathrm{~g}$ of CS. The mixture was stirred at $4 \mathrm{~g}$ for $10 \mathrm{~min}$, filtered through no. 4 Whatman paper and freeze-dried. The powdered extracts were stored in a dark and dry place until analysis. The sample $(37 \mathrm{mg} / \mathrm{ml}$ CSE solution) was filtered through a $0.45 \mu \mathrm{m}$ pore diameter nylon membrane syringe filter dry matter and $6.88 \pm 1.77 \mathrm{mg}$ CGA/g dry matter.

\subsection{Evaluation of the bioaccessibility of coffee silverskin extract}

\subsubsection{In vitro oral gastrointestinal digestion}

The amount of CSE components potentially available for further uptake was determined following the procedure of Hollebeeck, Borlon, Schneider, Larondelle, and Rogez (2013) with slight modifications. To mimic in vitro oral digestion, $1.17 \mathrm{~g}$ of CSE was suspended in $9 \mathrm{ml}$ of Milli-Q water and the $\mathrm{pH}$ was adjusted to 6.9 with $1 \mathrm{M} \mathrm{HCl}$ and brought to a volume of 9.98 ml. $\alpha$-Amilase $(0.45 \mathrm{ml}$ of $0.562 \mathrm{mg} / \mathrm{ml}$ in phosphate buffer) was added to each sample and 
incubated at $37^{\circ} \mathrm{C}$ for $5 \mathrm{~min}$ with constant stirring at $4 \mathrm{~g}$. For the gastric digestion step, $10 \mathrm{ml}$

137 of Milli-Q water was added and the $\mathrm{pH}$ of the samples was adjusted to 2.0 with $1 \mathrm{M} \mathrm{HCl}$. Pepsin $(110 \mu \mathrm{l}, 5 \mathrm{mg} / \mathrm{ml}$ in $0.1 \mathrm{M} \mathrm{HCl})$ was added to each sample and incubated in a final volume of $22.88 \mathrm{ml}$ at $37^{\circ} \mathrm{C}$ for 90 min under anaerobic conditions using an anaerobic chamber model Bactron II (Biogen, Weston, MA, USA) with constant stirring at $4 \mathrm{~g}$. After this time, the $\mathrm{pH}$ of the samples was adjusted to 7 with $1 \mathrm{M} \mathrm{NaHCO}_{3}$ for the intestinal digestion step. One $\mathrm{ml}$ of pancreatin solution $\left(287.59 \mathrm{mg} / \mathrm{ml}\right.$ in $\left.0.1 \mathrm{M} \mathrm{NaHCO}_{3}\right)$ was added, the final volume brought to $31.24 \mathrm{ml}$ with Milli-Q water, and the mixture was incubated at $37^{\circ} \mathrm{C}$ for $150 \mathrm{~min}$ under anaerobic conditions. Digested samples were centrifuged at $1677 \mathrm{~g}$ at $4{ }^{\circ} \mathrm{C}$ for $40 \mathrm{~min}$. Enzymatic activity was stopped with liquid $\mathrm{N}_{2}$ and supernatants were freeze-dried and stored under dark, dry conditions at $4{ }^{\circ} \mathrm{C}$ until analysis. The digestion of CSE was also carried out under the same conditions without adding the enzymes to gain insight into the effect of the $\mathrm{pH}$ in CGA and caffeine metabolism. Digestion experiments were carried out in triplicate.

\subsubsection{Chemical composition of digested and non-digested coffee silverskin extract}

Total phenolic content (TPC) was determined using the Folin-Ciocalteu's colorimetric assay (Singleton, Orthofer, \& Lamuela-Raventós, 1999) adapted to a microplate reader. Briefly, CSE prepared at $2 \mathrm{mg} / \mathrm{ml}$ was used. Ten $\mu \mathrm{l}$ of the sample was combined with $200 \mu \mathrm{l}$ of Folin reagent $(0.017 \%(\mathrm{v} / \mathrm{v}))$ and $50 \mu \mathrm{l}$ of $\mathrm{NaHCO}_{3}(30 \mathrm{mg} / \mathrm{ml})$. The 96 -well plate was incubated in darkness at room temperature for $2 \mathrm{~h}$ and was read at $725 \mathrm{~nm}$ using a BioTek PowerWave ${ }^{\mathrm{TM}} \mathrm{XS}$ mg of CGA equivalents per g of CSE (mg CGA /g CSE). The contents of CGA and caffeine in the CSE and their digested products was analyzed by capillary zone electrophoresis (CZE) as described by del ) del Castillo, Ames, and Gordon 
(2002). Previously, the digested CSE (10 mg of extract $/ \mathrm{ml}$ ) was filtered through $0.2 \mu \mathrm{m}$ nylon

filters (Symta, Madrid, Spain). Determinations were carried out in an Agilent G1600 A (Santa Clara, CA, USA) capillary electrophoresis instrument equipped with ChemStation software and a diode array detector (DAD). CZE was performed in an uncoated fused $48.5 \mathrm{~cm}$ long silica capillary (40 $\mathrm{cm}$ to the detector) with an internal diameter of $50 \mu \mathrm{m}$ and a $\mathrm{x} 3$ bubble cell. The other analysis conditions were as follows: $50 \mathrm{mM}$ sodium borate buffer $(\mathrm{pH} 9.5), 20 \mathrm{kV}$ voltage, $25{ }^{\circ} \mathrm{C}$ temperature and the injection was at 50 mbar for $5 \mathrm{~s}$. Electropherograms (egrams) were monitored at 200 and $280 \mathrm{~nm}$ for CGA and caffeine, respectively; and spectra collected from 190 to $600 \mathrm{~nm}$. The capillary was conditioned after running each sample by flushing with $0.1 \mathrm{M} \mathrm{NaOH}$ and buffer for $3 \mathrm{~min}$. CGA $(0.15-9 \mathrm{mM})$ and caffeine $(0.15-10 \mathrm{mM})$ calibration curves were used as standards for identification and quantification. Samples were analyzed in triplicate and results were expressed as mg of CGA or caffeine/g CSE.

\subsubsection{Antioxidant capacity of digested and non-digested coffee silverskin extract}

Antioxidant capacity was determined by the ABTS and ORAC $\mathrm{FL}_{\mathrm{FL}}$ assays, respectively. The ABTS assay was carried out according to Oki, Nagai, and Yoshinaga (2006). ABTS $^{\bullet+}$ was produced by reacting $7 \mathrm{mM}$ ABTS and $2.45 \mathrm{mM}$ potassium persulfate (final concentration in $10 \mathrm{ml}$ of water). The mixture was incubated in the dark at room temperature for $16 \mathrm{~h}$ before use. The aqueous $\mathrm{ABTS}^{\bullet+}$ solution was diluted 1:75 (v/v) with $5 \mathrm{mM}$ phosphate buffer (pH 7.4) obtaining an absorbance value of $0.7 \pm 0.02$ at $734 \mathrm{~nm}$. Thirty microlitres of sample $(0.2 \mathrm{mg}$ of non-digested CSE $/ \mathrm{ml}$ or $0.2 \mathrm{mg}$ of digested CSE/ml) or standard and $270 \mu \mathrm{l}$ of $\mathrm{ABTS}^{\bullet+}$ working solution were placed in each well. Absorbance readings were recorded in a microplate reader at $734 \mathrm{~nm}$ every minute. A standard calibration curve was constructed using Trolox (0.01-0.25 mM), and results were expressed as $\mu$ moles of Trolox equivalents (TE)/g of CSE. Another calibration curve using CGA, the major phenolic compound in coffee, was constructed 
(0.05-0.25 mM), and results were expressed as $\mu$ moles of CGA equivalents (CGA)/g of CSE.

Samples were analyzed in triplicate.

186

187

188

189

190

191

192

193

194

195

196

197

198

199

200

201

202

203

204

205

206

An aliquot of non-digested CSE $(10 \mathrm{mg} / \mathrm{ml})$ was subjected to fractionation using an Amicon ${ }^{\circledR}$

Ultra $0.5 \mathrm{ml}$ centrifugal filter unit fitted with an Ultracel ${ }^{\circledR}-10 \mathrm{~K}$ regenerated cellulose membrane (10 kDa cut-off) (Merck Millipore, Darmstadt, Germany). The antioxidant capacity of low (< $10 \mathrm{kDa})$ and high $(\geq 10 \mathrm{kDa})$ molecular weight fractions was also analysed using the $\mathrm{ABTS}^{\circ+}$ assay.

The $\mathrm{ORAC}_{\mathrm{FL}}$ assay was performed following the procedure described by Huang, Ou, Hampsch-Woodill, Flanagan, and Prior (2002). Briefly, $25 \mu 1$ of sample of the appropriate dilution or standard were added to a 96-well microplate followed by the addition of $150 \mu 1$ of fluorescein work solution $\left(8.5 \times 10^{-5} \mathrm{mM}\right)$ prepared in $75 \mathrm{mM}$ phosphate buffer $(\mathrm{pH} 7.4)$. The Biotek Synergy ${ }^{\mathrm{TM}}$ HT microplate reader (Biotek Instruments, Highland Park, Winooski, VT, USA) was programmed to incubate the plate at $37^{\circ} \mathrm{C}$ and add $30 \mu 1$ of AAPH solution (153 $\mathrm{mM}$ in phosphate buffer) as a peroxyl radical generator. Fluorescence was read with excitation at $485 \mathrm{~nm}$ and emission at $528 \mathrm{~nm}$ every two minutes for $90 \mathrm{~min}$. A blank consisting of fluorescein, AAPH and phosphate buffer was also included. Calibration curves of Trolox (6.25$50 \mu \mathrm{M})$ and CGA (3.12-25 $\mu \mathrm{M})$ were constructed. Standard calibration curves were composed by plotting the net area under the curve (AUC) as a function of Trolox or CGA concentration. ORAC $_{\mathrm{FL}}$ values were expressed as $\mu$ moles TE/g of CSE and as $\mu$ moles CGA/g of CSE.

\subsection{Animals and the experimental design (ARRIVE guidelines)}

The experimental protocols were approved by the Ethical Committee for the Use of Laboratory Animals of the UGR, Universidad de Granada, Campus de la Cartuja, GR, Spain (CEEA: 2010287). 
CSE doses administrated to the animals in vivo provided 0.150 and $0.434 \mathrm{mg} / \mathrm{d}$ of CGA and caffeine, respectively. CGA and caffeine dose selection was based on moderate coffee consumption ( 3 cups a day) in adults (del Castillo, Ames \& Gordon, 2002; Heckman, Weil \& Gonzalez de Mejia, 2010), and the CSE dose was limited by its caffeine content (max. 300 mg/day).

\subsubsection{Evaluation of the bioavailability of coffee silverskin extract}

Twelve 6-week-old male Wistar rats (ENVIGO, Alconbury, United Kingdom) were housed singly in metabolic cages with free access to standard food (2014S Teklad, ENVIGO, Alconbury, United Kingdom) and water ad libidum. Food and water intake were measured by subtracting the remaining amount of food and water in the containers from the total amount given the day before, during the bioavailability study. Animals were divided into four groups $(n=4)$ : rats treated with CSE, rats treated with CGA, rats treated with caffeine and untreated rats (control). At 8:00 in the morning, the CSE group received one single dose of CSE (containing $2.2 \mathrm{mg}$ caffeine/kg body weight; $0.8 \mathrm{mg} \mathrm{CGA} / \mathrm{kg}$ body weight), the CGA group received pure CGA (1.5 mg CGA/kg body weight) and the caffeine group received pure caffeine $(5 \mathrm{mg} / \mathrm{kg}$ body weight). Urine samples were then serially collected from treated rats every hour for 6 hours, then every $2 \mathrm{~h}$ up to $10 \mathrm{~h}$ and finally after $24 \mathrm{~h}$. Urine samples were collected from untreated rats every 24 hours as a control. Samples were stored at $-80{ }^{\circ} \mathrm{C}$ until analysis. After 3 days of clearance, the bioavailability experiments were repeated with the same animals.

Urinary creatinine was measured with the creatinine quantitative test kit (SPINREACT, Gerona, Spain) based on the Jaffe reaction, as previously described by Murray (1984). MS/MS. Urine samples were defrosted, centrifuged at $10481 \mathrm{~g}$ for $10 \mathrm{~min}$ at $4{ }^{\circ} \mathrm{C}$ and 
supernatants were filtered using a $0.45 \mu \mathrm{m}$ pore-size nylon membrane syringe filter (Análisis Vínicos, Ciudad Real, Spain). Aliquots $(10 \mu \mathrm{l})$ were analysed in triplicate using an Accela liquid chromatograph (Thermo Scientific, San Jose, CA, USA) equipped with a DAD and an autosampler. The chromatograph was coupled to a TSQ TSQ Quantum (Thermo Scientific) triple quadrupole analyzer via an electrospray ionization (ESI) interface. Xcalibur software (Thermo Scientific) was used for data storage and evaluation. Analytical conditions consisted of a ZORBAX SB-C18 $(50 \mathrm{~mm} \times 2.1 \mathrm{~mm}$ and $1.8 \mu \mathrm{m}$ of particle diameter) column (Thermo Scientific) using $1 \%(\mathrm{v} / \mathrm{v})$ formic acid in methanol and $1 \%(\mathrm{v} / \mathrm{v})$ formic acid in Milli-Q water as A and B mobile phases, respectively. Elution was carried out according to the following gradient: $0 \mathrm{~min}, 95 \% \mathrm{~B} ; 0.35 \mathrm{~min}, 95 \%$ $\mathrm{B} ; 7$ min, $80 \%$ $\mathrm{B} ; 9.5 \min , 5 \% \mathrm{~B} ; 10 \mathrm{~min} ; 95 \% \mathrm{~B} ; 15$ $\min , 95 \%$ B. Optimum flow rate was $0.3 \mathrm{ml} / \mathrm{min}$, whereas the injection volume was $10 \mu \mathrm{l}$. The DAD recorded the spectra from 200 to $450 \mathrm{~nm}$. Column and autosampler compartments were kept at $30{ }^{\circ} \mathrm{C}$ and $4{ }^{\circ} \mathrm{C}$, respectively. The mass spectrometer was operated in the positive ESI mode to quantify caffeine and paraxanthine and in the negative ESI mode to quantify CGA and HA. Spray voltage and capillary temperature were set at $3500 \mathrm{~V}$ and $250{ }^{\circ} \mathrm{C}$, respectively. Nitrogen was used as a sheath and auxiliary gas at pressures of 40 and 20 arbitrary units, respectively. Ion sweep gas pressure was 2 units and collision gas (Ar) pressure was $190 \mathrm{mPa}$. Scan width and scan time were fixed at $0.020(\mathrm{~m} / \mathrm{z})$ and $0.100 \mathrm{~s}$, respectively, and the system was operated in selected reaction monitoring (SRM). SRM parameters were optimized by direct infusion of standards. Two transition ions were monitored for identification but only the most intense one for each precursor ion was used for quantification. Parent $\left([\mathrm{M}-\mathrm{H}]^{-}\right)$and product ions for CGA and HA were $\mathrm{m} / \mathrm{z} 353.2 \rightarrow 191.1$ and $\mathrm{m} / \mathrm{z} 178.3 \rightarrow 134.3$, respectively, whereas parent $\left([\mathrm{M}-\mathrm{H}]^{+}\right)$and product ions for caffeine and paraxanthine were $\mathrm{m} / \mathrm{z} 195.1 \rightarrow$ 


\subsubsection{Evaluation of the bioactivity of coffee silverskin extract in the pancreas of streptozotocin-nicotinamide diabetic rats}

Thirty-two 6-week-old male Wistar rats (ENVIGO, Alconbury, United Kingdom) were divided into four groups $(\mathrm{n}=8)$ paired by weight (average weight per group was $194 \pm 2 \mathrm{~g})$. Rats were maintained at $23 \pm 1{ }^{\circ} \mathrm{C}$ and $55 \pm 5 \%$ relative humidity on a $12: 12$-hour light-dark cycle with free access to standard food (2014S Teklad, ENVIGO, Alconbury, United Kingdom) and water ad libidum. Food and water intake were measured by subtracting the remaining amount of food and water in the containers from the total amount given the day before, during the experimental time. The rats in groups 1, 2 and 3 were supplemented by gastric gavage with CSE $(2.2 \mathrm{mg}$ caffeine/kg body weight, $0.8 \mathrm{mg}$ CGA/ kg body weight), pure CGA (1.5 mg CGA/kg body weight) and pure caffeine ( $5 \mathrm{mg}$ caffeine $/ \mathrm{kg}$ body weight) dissolved in $1 \mathrm{ml}$ of sterile water, respectively, every day for a total of 42 days. The fourth group (the STZ group) was treated similarly with sterile water. At day 35, all rats were injected with $200 \mathrm{mg} / \mathrm{kg}$ body weight of NA dissolved in saline buffer, and 15 min later T2DM was induced by the intraperitoneal injection of $60 \mathrm{mg} / \mathrm{kg}$ body weight of STZ dissolved in cold $0.1 \mathrm{M}$ citrate buffer ( $\mathrm{pH} 4.5$ ) immediately before use, according to Masiello et al. (1998). The order in which the animals were injected was randomized among the groups. Blood samples were obtained from the tail vein and glucose levels $(\mathrm{mg} / \mathrm{dl})$ were determined after T2DM induction every day for six days using a glucometer (FreeStyle Lite ${ }^{\circledR}$, Abbott Laboratories). Rats were considered diabetic when blood glucose levels were above $200 \mathrm{mg} / \mathrm{dl}$. An additional healthy control group $(\mathrm{n}=8)$ was also included in the experiment.

At day 42, overnight-fasting blood glucose was measured using a glucometer. The fasting rats were then anaesthetised with Ketamine-Xylazine $(1 \mathrm{ml} / \mathrm{kg}$ body weight and $0.5 \mathrm{ml} / \mathrm{kg}$ body weight, respectively) and sacrificed. The pancreas was removed promptly, weighed, divided into three parts and stored at $-80^{\circ} \mathrm{C}$ until required. 
Glutathione peroxidase (GPx) and GR activity were determined in pancreas homogenates as described by Rodríguez-Ramiro, Martín, Ramos, Bravo, and Goya (2011). Thus, pancreatic tissues were homogenized (1:5 w/v) in $0.25 \mathrm{M}$ Tris, $0.2 \mathrm{M}$ sucrose and $5 \mathrm{mM}$ DTT buffer $\mathrm{pH}$ 7.4 and centrifuged at $3000 \mathrm{~g}$ for $15 \mathrm{~min}$. Determination of GPx activity was based on the oxidation of GSH by GPx, using t-BOOH as a substrate, coupled to the disappearance of NADPH catalysed by GR which reduced GSSG. GR activity was determined based on the decrease in absorbance due to the oxidation of NADPH used in the reduction of GSSG. Total pancreatic protein content was measured by the Bradford method (Bradford, 1976).

GSH concentration was evaluated using the previously described fluorometric assay ( Rodríguez-Ramiro, Martín, Ramos, Bravo, \& Goya, 2011). This method takes advantage of the reaction of GSH with $o$-phthaldehyde at $\mathrm{pH}$ 8.0. Pancreatic tissues were homogenized (1:20 $\mathrm{w} / \mathrm{v}$ ) in $50 \mathrm{mM}$ phosphate buffer $\mathrm{pH} 7.0$, and proteins were precipitated with 5\% trichloroacetic acid and then centrifuged for $30 \mathrm{~min}$ at $10.000 \mathrm{~g}$. Fluorescence was measured at an emission wavelength of $460 \mathrm{~nm}$ and an excitation wavelength of $340 \mathrm{~nm}$. Results were interpolated in a GSH standard curve (5-1000 ng) and expressed as nmol/mg protein.

Pancreatic protein oxidation was measured as carbonyl groups content according to GranadoSerrano, Martín, Bravo, Goya, and Ramos (2009). Pancreatic tissues were homogenized (1:5 w/v) in $0.25 \mathrm{M}$ Tris, $0.2 \mathrm{M}$ sucrose and $5 \mathrm{mM}$ DTT buffer $\mathrm{pH} 7.4$ and centrifuged at $3000 \mathrm{~g}$ for $15 \mathrm{~min}$. Absorbance was measured at $360 \mathrm{~nm}$, and carbonyl content was expressed as $\mathrm{nmol} / \mathrm{mg}$ protein using an extinction coefficient of $22000 \mathrm{nM} / \mathrm{cm}$. Total pancreatic protein content was measured by the Bradford reagent.

\subsection{Data analysis}

SPSS program version 22.0 was used for statistical analyses. Comparisons of excretion pharmacokinetic parameters between treatments were done by Student's T-test. Kolmogorov- 
Smirnov test and Q-Q graphics were used to test normality for the distribution of values by group of treatment. The normality assumption was met for all data by group of treatment. Prior to statistical analysis, all data were tested for homogeneity of variances using the Levene's test in order to determine the appropriate statistical technique to be used for comparing means between groups of treatmentsTo compare TPC, CGA and caffeine content of non-digested CSE, digested CSE and CSE digested control (absence of enzymes) multiple comparisons were carried out using one-way ANOVA followed by Bonferroni test when variances were homogeneous or by Games-Howell test when variances were not. Antioxidant capacity between CSE non-digested and CSE digested were analyzed with a T-test for dependent samples, using the adjustment for heterogeneous variances when necessary. Maximum concentration $\left(\mathrm{C}_{\max }\right)$, AUC and the time required to reach maximum concentration $\left(\mathrm{T}_{\max }\right)$ of metabolites in urine was evaluated using Microsoft Excel functions (Usansky, Desai, \& TangLiu, 2010). To compare pharmacokinetic parameters of hippuric acid a multiple comparisons, one-way ANOVA technique with the application of the Snedecor's F-test was carried out followed by a Sidak posthoc test when variances were homogeneous (AUC and $\mathrm{T}_{\max }$ ) or by the T3 Dunnet posthoc test when variances were not homogeneous $\left(\mathrm{C}_{\max }\right)$. To compare pharmacokinetic parameters of caffeine and paraxanthine, a T-test for independent samples were performed, using the adjustment for heterogeneity when necessary. Carbonyl content, GSH, GR and GPx activity comparisons between treatments were analyzed by one-way ANOVA followed by Bonferroni test when variances were homogeneous or by T3-Dunnet posthoc test when variances were not. The level of significance was $p<0.05$ except in the case of carbonyl content $(\mathrm{p}<0.1)$.

\section{Results}


328 TPC and CGA and caffeine levels of $46.65 \mathrm{mg} / \mathrm{g}, 13.33 \mathrm{mg} / \mathrm{g}$ and $44.64 \mathrm{mg} / \mathrm{g}$ were detected in

329 CSE, respectively. Overall antioxidant capacity values of 397 and $358 \mu \mathrm{mol} \mathrm{CGA/g}$ (corresponding to 427 and 816 of $\mu \mathrm{mol} \mathrm{TE} / \mathrm{g}$ ) were obtained for scavenging and hydrogen donating capacities in CSE, respectively (Table 1). The antioxidant capacity of low molecular weight compounds $(<10 \mathrm{kDa})$ was $220 \mu \mathrm{mol} \mathrm{CGA} / \mathrm{g}$, while the antioxidant capacity of the fraction containing high molecular weight compounds $(\geq 10 \mathrm{kDa})$ was $110 \mu \mathrm{mol} \mathrm{CGA} / \mathrm{g}$. In vitro digestion of CSE decreased concentrations of caffeine (25\%), TPC (40\%) and CGA (82\%). The overall antioxidant capacity of CSE as measured by ABTS and ORAC decreased by $15 \%$ and $50 \%$, respectively (Table 1 ).

To evaluate the effect of changes in $\mathrm{pH}$ during digestion on the degradation of bioactive compounds, a digestion in the absence of digestive enzymes was performed. Changes in $\mathrm{pH}$ decreased TPC and CGA content by $38 \%$ and $83 \%$, respectively, while caffeine content only decreased by $15 \%$.

CSE can provide bioaccessible amounts of bioactive compounds such as TPC $(79.26 \mu \mathrm{mol} / \mathrm{g})$, CGA $(6.86 \mu \mathrm{mol} / \mathrm{g})$ and caffeine $(172.37 \mu \mathrm{mol} / \mathrm{g})$. Digests presented antioxidant capacities of $337 \mu \mathrm{mol} / \mathrm{g}$ and $179 \mu \mathrm{mol} / \mathrm{g}$ by ABTS and ORAC assays, respectively.

\subsection{Metabolism of the bioactive compounds of coffee silverskin extract}

Figure 1 shows the kinetics of the urinary excretion of CGA, caffeine and their metabolites. Urinary pharmacokinetic parameters of these compounds after CSE, caffeine and CGA consumption are presented in Table 2. Intact CGA was not found in the urine of rats fed with CSE (containing $0.150 \mathrm{mg}$ of CGA/day), CGA (0.293 mg of CGA/day) or caffeine. The baseline value of $\mathrm{HA}$ in urine excretion was set at $431.7 \mu \mathrm{mol} / \mathrm{mmol}$ creatinine and was obtained by measuring HA in the $24 \mathrm{~h}$ urine of the animals before administering the products. HA excretion was the greatest after the ingestion of CGA, reaching a peak in the $0-2 \mathrm{~h}$ interval, and AUC was significantly higher than that found after the intake of CSE and caffeine $(\mathrm{p}<$ 
3530.001 and $\mathrm{p}=0.017$, respectively) (Table 2). The maximum concentration of HA in urine 354 (1346.9 mmol/ $\mu \mathrm{mol}$ creatinine) was found $1.6 \mathrm{~h}$ after CGA consumption, which was higher than the maximum HA concentrations found in urine after CSE intake $(\mathrm{p}<0.008)$ (Figure 1A and Table 2).

357 Excretion of caffeine and its metabolite paraxanthine were not detected in the urine of CGA treated rats. Non-metabolized caffeine in urine excretion after the consumption of pure caffeine was higher than that found after treatment with CSE $(p<0.001$ for AUC and $p=0.001$ for $\mathrm{C}_{\max }$ ) (Figure 1B and Table 2). Urinary excretion of caffeine was almost completed before $12 \mathrm{~h}$ in rats treated with caffeine or with the CSE (Figure 1B).

Urinary paraxanthine excretion after consumption of pure caffeine tended to be higher than that found after the intake of CSE ( $p=0.056$ for $\mathrm{AUC}$ and $\mathrm{p}=0.050$ for $\mathrm{C}_{\max }$ ) (Figure $1 \mathrm{C}$ and Table 2).In this case, paraxanthine needed $24 \mathrm{~h}$ to be completely excreted in urine after the intake of both CSE and caffeine (Figure 1C).

Both studied compounds were metabolized. Free CGA was not detected in urine and caffeine was metabolized to paraxanthine.

\subsection{Bioactivity of coffee silverskin extract in the pancreas of streptozotocin-} nicotinamide diabetic rats

The effect of the CSE, CGA and caffeine treatments on oxidative stress biomarkers in the pancreas of diabetic rats is shown in Figure 2. Rats were considered diabetic when blood glucose levels were above $200 \mathrm{mg} / \mathrm{dl}$. The STZ-NA treatment caused significant oxidation (p $<0.1$ ) of pancreatic proteins by increasing their carbonyl groups (Figure 2A). On the contrary, animals pre-treated with CGA or caffeine for $35 \mathrm{~d}$ significantly prevented $(\mathrm{p}<0.1)$ oxidative protein damage induced by STZ. Protein carbonyl content decreased by $24 \%$ and $22 \%$ in the pancreas of diabetic rats treated with CGA and caffeine, respectively. However, CSE did not 
reduce the rate of protein oxidation induced by the toxic agent. GSH content in the pancreas of T2DM rats decreased significantly $(\mathrm{p}<0.05)$ (Figure 2B), and pre-treatment with CSE and CGA significantly reduced $(\mathrm{p}<0.05)$ GSH depletion in the pancreas of diabetic rats. Untreated rats and those treated with CSE and CGA showed similar pancreatic GSH values ( $p>0.05)$. GPX and GR values of all animals were of the same order of magnitude ( $p>0.05)$ (Figure 2C).

The physiological concentrations of the bioactive compounds forming CSE were able to protect pancreatic cells against oxidative stress produced by the diabetogenic agent STZ.

\section{Discussion}

This is the first study assessing the role of the gastrointestinal digestion on the bioaccessibility of CSE bioactive compounds and its remnant overall antioxidant capacity.

TPC values found in CSE are in agreement with those described by other authors (MartinezSaez et al., 2014; Mesías et al., 2014). Slightly higher CGA and caffeine concentrations were found in CSE than in CS raw material (4.31 mg CGA/g and $10 \mathrm{mg}$ caffeine/g) using a similar analytical method (Bresciani, Calani, Bruni, Brighenti, \& Del Rio, 2014). Results suggest that aqueous extraction increases the bioaccessibility of the bioactive compounds present in the plant matrix. Values of overall antioxidant capacity also agree with those reported by Mesías et al. (2014). The highlighted chemical composition of CSE suggests that it could be a good source of bioactive compounds with putative healthy benefits (del Castillo, Fernandez-Gomez, Martinez-Saez, Iriondo, \& Mesa, in press).

Our results indicate that in vitro digestion affected the composition of CSE reducing the bioaccessibility of TPC, CGA and caffeine. However, digests presented antioxidant capacity suggesting that antioxidants remained bioaccessible after the digestion process. The release of compounds from the plant matrix depends on the chemical form and the properties of nutrients and phytochemicals (Holst \& Williamson, 2008). TPC and CGA contents were significantly 
decreased $(\mathrm{p}<0.05)$ by the digestion processes (data not shown). Since this decrease was observed in the absence of digestive enzymes, it may be associated with changes in $\mathrm{pH}$ taking place during in vitro digestion. Several studies have shown that the bioaccessibility of TPC in different food matrixes was lower than that found for isolated polyphenols. Podio et al. (2015) observed a 5-fold lower TPC content in digested coffees than in native instant coffees. CamposVega et al. (2015) reported a considerable reduction of TPC (91\%) in spent coffee grounds. Akillioglu and Karakaya (2010) showed that the bioaccessibility of TPC ranged from 19\% to $39 \%$ in bean varieties. Phenolic compounds are less bioaccessible partly due to the presence of dietary fiber in the plant matrix (Palafox-Carlos, Ayala-Zavala, \& González-Aguilar, 2011). CSE contains high amounts of dietary fiber $(362 \mathrm{mg} / \mathrm{g})$ which affect the release of TPC in the digestion process. Hydroxycinnamic acid derivatives constitute the main phenolic component of CS (Bresciani, Calani, Bruni, Brighenti, \& Del Rio, 2014).Vallejo, Gil-Izauierdo, Pérez Vicente, and García-Viguera (2004) observed an $87 \%$ decrease in CGA after intestinal digestion. Previous studies have suggested that a $\mathrm{pH}$ value of 7.5 and bile salts could contribute to lower CGA. Bermúdez-Soto, Tomás-Barberán, and García-Conesa (2007) reported a minor decrease in CGA (5\%) in chokeberry extract due to the $\mathrm{pH}$ of intestinal digestion ( $\mathrm{pH} 7.5)$. However, a bioaccessibility study of CGAs in spent coffee grounds showed a total recovery of this compound after digestion (Monente et al., 2015). These differences in CGA release suggest that bioaccessibility is also affected by the plant matrix.

In agreement with the data on TPC and CGAs, overall antioxidant capacity also decreased after in vitro gastrointestinal digestion. The main antioxidant compounds reported in CSE are CGAs, melanoidins and antioxidant fiber (Fernandez-Gomez, Martinez-Saez, Iriondo, \& Mesa, in press). According to our data, low molecular weight compounds (CGAs, other phenols and caffeine among others) seem to make a greater contribution to the in vitro overall antioxidant capacity of CSE than the high molecular weight fraction (melanoidins, proteins and antioxidant 
fiber). Rice-Evans, Miller and Paganga (1996) found that CGA antioxidant activity is related

427 to the $\mathrm{CH}=\mathrm{CH}-\mathrm{COOH}$ group, which ensures greater $\mathrm{H}$-donating ability and radical

428

429

430

431

432

433

434

435

436

437

438

439

440

441

442

443

444

445

446

447

448

449

450

stabilization. Caffeine effectively reacts with the hydroxyl radical $(\mathrm{OH} \cdot)$ and caffeine-derived oxygen-centered radicals are formed in the reaction between caffeine and OH (Shi, Dalal, \& Jain, 1991). In this sense, Pellegrini et al. (2003) found a decrease of $\sim 25-30 \%$ in the antioxidant capacity of espresso coffee when the caffeine was removed.

The greatest part of the CGA ingested by rats is hydrolyzed to caffeic acid and quinic acid, and further metabolized by gut microbiota into various aromatic acid metabolites including $\mathrm{m}$ coumaric acid and derivatives of phenylpropionic and benzoic acids (Figure 3) (Gonthier, Verny, Besson, Rémésy, \& Scalbert, 2003). Previous studies found that HA, a benzoic acid, was the major CGA-derived metabolite observed in urine and plasma after the ingestion of pure CGA or CGA from a food matrix (Gonthier, Verny, Besson, Rémésy, \& Scalbert, 2003; Mulder, Rietveld, \& van Amelsvoort, 2005). We found amounts of HA in urine of 1346.9 $\mathrm{mmol} / \mu \mathrm{mol}$ creatinine after the intake of a single dose of $0.825 \mu \mathrm{mol}$ CGA. Urine HA concentration after the intake of CSE containing $0.424 \mu \mathrm{mol}$ CGA $(447.9 \mathrm{mmol} / \mu \mathrm{mol}$ creatinine) was of the same order of magnitude as basal values $(431.7 \mathrm{mmol} / \mu \mathrm{mol}$ creatinine $)$. These results are in agreement with the low bioaccessibility observed for the CGA present in CSE. The metabolic fate of CGAs ingested as a pure compound or present in coffee has been previously investigated in rats (Choudhury, Srai, Debnam, \& Rice-Evans, 1999; Gonthier, Verny, Besson, Rémésy, \& Scalbert, 2003) and humans (Monteiro, Farah, Perrone, Trugo, \& Donangelo, 2007; Stalmach, Williamson, \& Crozier, 2014). Farah, Monteiro, Donangelo, and Lafay (2008) reported high bioavailability of CGAs present in a green coffee extract in humans. In this study, we did not detect intact CGA in urine after oral dosing of CGA and CSE. Results suggest that CGA was absorbed and metabolized into different compounds to those tested in the present study. In accordance with our findings, several authors failed to detect CGA in the 
plasma or urine of rats and humans fed pure CGA or CGA-containing foods (Booth, Emerson, Jones, \& Deeds, 1957; Choudhury, Srai, Debnam, \& Rice Evans, 1999; Azuma et al., 2000;

Nardini, Cirillo, Natella, \& Scaccini, 2002; Stalmach, Williamson, \& Crozier, 2014).

CSE is also a good source of caffeine (1,3,7-trimethylxanthine). Methylxanthines are extensively absorbed in the gastrointestinal tract and metabolized in the liver to yield methylxanthine derivatives and methyluric acids as the main metabolites, which are finally excreted in urine (Figure 3) (Martínez-López et al., 2014). Paraxanthine (1,7 dimethylxanthine) is the main metabolite of caffeine biotransformation found in plasma and urine after caffeine intake (Arnaud, 2011). The pharmacokinetics of caffeine and paraxanthine excretion were evaluated after the consumption of $5.026 \mu$ mol pure caffeine and CSE containing $2.211 \mu \mathrm{mol}$ caffeine. Caffeine was present in the urine of both groups of rats, which is in agreement with other studies that described incomplete biotransformation in humans (Bonati et al., 1982; Rodopoulos, Wisén, \& Norman, 1995). According to CSE composition, the lower consumption of caffeine was in line with the lower excretion observed for this compound and its metabolite paraxanthine. These results are in agreement with previous findings of dose-dependent metabolism and the excretion of caffeine in humans (Martínez-López et al., 2014). Therefore, our data showed that the caffeine present in CSE is bioavailable, partially metabolized, and rapidly excreted.

The in vivo effect of CGA, caffeine and CSE on the prevention of oxidative damage in the pancreas of STZ-NA-induced T2DM rats was also evaluated. The cytotoxic action of STZ is associated with the generation of ROS and consequent $\beta$-cell destruction and suppression of insulin secretion (Szkudelski, 2001). Antioxidants are able to prevent pancreatic islets damage induced by STZ (Fernandez-Alvarez et al., 2004). Consequently, natural antioxidants may be considered promising candidates for the prevention or co-treatment of diabetes. In the present study, the administration of STZ to the animals produced a decrease in GSH and an increase in 
476 GR activity $(\mathrm{p}=0.173)$, while GPx activity remained unaltered in pancreas antioxidant defense.

477 This indicates that the depletion of GSH may induce GR activity but this induction is not 478 enough to regenerate the basal GSH concentration. Protein oxidation was significant $(\mathrm{p}<0.1)$ 479 in the pancreas of STZ induced T2DM rats. Interestingly, the daily administration of CSE, 480 CGA or caffeine $35 \mathrm{~d}$ previous to the induction of diabetes significantly prevented $(\mathrm{p}<0.05)$ pancreatic oxidative stress. Treatments with CGA and caffeine significantly inhibited cellular protein damage. In vitro studies have shown that CGA (Ahn et al., 2014; Deng et al., 2013; Nam et al., 2015) and caffeine (Chen, Yu, Shen, Xia, \& Xu, 2015) protect pancreatic $\beta$-cells from the oxidative stress damage caused by free radicals. Furthermore, in vivo studies have demonstrated that CGA (Karthikesan, Pari, \& Menon, 2010) and caffeine (Abunasef, Amin, \& Abdel-hamid, 2014; Kagami, Morita, Onda, Hirano, \& Oka, 2008) could also prevent STZinduced oxidative stress and protect $\beta$-cells in vivo. The present study is the first to demonstrate a specific chemo-protective effect of CSE on pancreas tissue, possibly associated to its antioxidant capacity.

In conclusion, the present study provides, for the first time, information on the bioaccessibility, metabolism and in vivo bioactivity of bioactive compounds present in CSE. The bioaccessibility of CGA and caffeine was affected by changes in $\mathrm{pH}$ during digestion. CGA $(0.91 \mu \mathrm{mol})$ and caffeine $(5.53 \mu \mathrm{mol})$ were metabolized and protected pancreatic cells against the oxidative stress induced by the diabetogenic agent. 
498 Acknowledgments

499 This work was supported by the grants SUSCOFFEE (AGL2014-57239-R) and SAMID

500 (RD12/0026). B. Fernandez-Gomez thanks PhD. program of MINECO for supporting her

501 research career (BES-2011-046827). The authors thank Llenalia García Fernández for

502 statistical analysis.

503 Conflict of interest

504 The authors declare that there are no conflicts of interest. 


\section{References}

Abunasef, S. K., Amin, H. A., \& Abdel-hamid, G. A. (2014). A histological and immunohistochemical study of beta cells in streptozotocin diabetic rats treated with caffeine, 52, 42-50.

Ahn, H. R., Lee, H. J., Kim, K. A., Kim, C. Y., Nho, C. W., Jang, H., \& Jung, S. H. (2014). Hydroxycinnamic acids in Crepidiastrum denticulatum protect oxidative stress-induced retinal damage. Journal of Agricultural and Food Chemistry, 62, 1310-23. http://doi.org/10.1021/jf4046232

Akillioglu, H. G., \& Karakaya, S. (2010). Changes in total phenols, total flavonoids, and antioxidant activities of common beans and pinto beans after soaking, cooking, and in vitro digestion process. Food Science and Biotechnology, 19, 633-639. http://doi.org/10.1007/s10068-010-0089-8

Arnaud, M. J. (2011). Pharmacokinetics and metabolism of natural methylxanthines in animal and man. Handbook of Experimental Pharmacology, 200, 33-91. http://doi.org/10.1007/978-3-642-13443-2_3

Azuma, K., Ippoushi, K., Nakayama, M., Ito, H., Higashio, H., \& Terao, J. (2000). Absorption of chlorogenic acid and caffeic acid in rats after oral administration. Journal of Agricultural and Food Chemistry, 48, 5496-5500. http://doi.org/10.1021/jf000483q

Bermúdez-Soto, M., Tomás-Barberán, F., \& García-Conesa, M. (2007). Stability of polyphenols in chokeberry (Aronia melanocarpa) subjected to in vitro gastric and pancreatic digestion. Food Chemistry, 102, 865-874. http://doi.org/10.1016/j.foodchem.2006.06.025

Bonati, M., Latini, R., Galletti, F., Young, J. F., Tognoni, G., \& Garattini, S. (1982). Caffeine disposition after oral doses. Clinical Pharmacology and Therapeutics, 32, 98-106.

Booth, A. N., Emerson, O. H., Jones, F. T., \& Deeds, F. (1957). Urinary metabolites of caffeic acid and chlorogenic acids. The Journal of Biological Chemistry, 229, 51-59.

Bradford, M. (1976). A rapid and sensitive method for the quantitation of microgram quantities of protein utilizing the principle of protein-dye binding. Analytical Biochemistry, 72, 24854.

Bresciani, L., Calani, L., Bruni, R., Brighenti, F., \& Del Rio, D. (2014). Phenolic composition, caffeine content and antioxidant capacity of coffee silverskin. Food Research International, 61, 196-201. http://doi.org/10.1016/j.foodres.2013.10.047

Campos-Vega, R., Vázquez-Sánchez, K., López-Barrera, D., Loarca-Piña, G., Mendoza-Díaz, S., \& Oomah, B.D. (2015). Simulated gastrointestinal digestion and in vitro colonic fermentation of spent coffee (Coffea arabica L.): Bioaccessibility and intestinal permeability. Food Research International, 77, 156-161. http://doi.org/156-161. 10.1016/j.foodres.2015.07.024

Chen, L., Yu, M., Shen, T., Xia, J., \& Xu, B. L. (2015). Impact of caffeine on $\beta$ cell proliferation and apoptosis under the influence of palmitic acid. Genetics and Molecular Research, 14, 5724-5730. http://doi.org/10.4238/2015.May.29.4

Choudhury, R., Srai, S. K., Debnam, E., \& Rice-Evans, C. A. (1999). Urinary excretion of hydroxycinnamates and flavonoids after oral and intravenous administration. Free Radical Biology and Medicine, 27, 278-286. http://doi.org/10.1016/S0891- 
del Castillo, M. D., Ames, J. M., \& Gordon, M. H. (2002). Effect of roasting on the antioxidant activity of coffee brews. Journal of Agricultural and Food Chemistry, 50, 3698-3703.

del Castillo, M. D., Ibañez, E., Amigo-Benavent, M., Herrero, M., Plaza, M., \& Ullate, M. (2013a). Application of products of coffee silverskin in anti-ageing cosmetics and functional food. WO 2013/004873.

del Castillo, M. D., Martinez-Saez, N., Amigo-Benavent, M., \& Silvan, J. M. (2013b). Phytochemomics and other omics for permitting health claims made on foods. Food Research International, 54, 1237-1249.

del Castillo, M. D., Fernandez-Gomez, B., Ullate, M., \& Mesa, M. D. (2014). Uso de productos de la cascarilla de café para la prevención y tratamiento de las patologías que conforman el síndrome metabólico y de sus factores de riesgo. P201431848.

del Castillo, M. D., Fernandez-Gomez, B., Martinez-Saez, N., Iriondo, A. \& Mesa, M. D. (in press). Coffee By-Products. In A. Farah (Ed.), Coffee: Chemestry, Quality and Health Implications. RSC Publishing Inc.

Deng, J., Qi, X. L., Guan, Z. Z., Yan, X. M., Huang, Y., \& Wang, Y.L. (2013). Pretreatment of SH-SY5Y cells with dicaffeoylquinic acids attenuates the reduced expression of nicotinic receptors, elevated level of oxidative stress and enhanced apoptosis caused by $\beta$-amyloid peptide. The Journal of Pharmacy and Pharmacology, 65, 1736-1744. http://doi.org/10.1111/jphp.12096

Farah, A., Monteiro, M., Donangelo, C, M., \& Lafay, S. (2008). Chlorogenic acids from green coffee extract are highly bioavailable in humans. The Journal of Nutrition, 138, 23092315. http://doi.org/10.3945/jn.108.095554

Fernandez-Alvarez, J., Barberà, A., Nadal, B., Barceló-Batllori, S., Piquer, S., Claret, M., \& Gomis, R. (2004). Stable and functional regeneration of pancreatic beta-cell population in nSTZ-rats treated with tungstate. Diabetologia, 47, 470-477. http://doi.org/10.1007/s00125-004-1332-8

Fernandez-Gomez, B., Ullate, M., Picariello, G., Ferranti, P., Mesa, M. D. \& del Castillo, M. D. (2015). New knowledge on the antiglycoxidative mechanism of chlorogenic acid. Food \& Function, 6, 2081-2090.

Fernandez-Gomez, B., Ramos, S., Goya, L., Mesa, M.D., del Castillo, M.D., \& Martín, M. A. (in press). Coffee silverskin extract improves glucose-stimulated insulin secretion and protects against streptozotocin-induced damage in pancreatic INS-1E beta cells. Food Research International. doi:10.1016/j.foodres.2016.03.006

Gonthier, M. P., Verny, M.A., Besson, C., Rémésy, C., \& Scalbert, A. (2003). Chlorogenic acid bioavailability largely depends on its metabolism by the gut microflora in rats. The Journal of Nutrition, 133, 1853-1859.

Granado-Serrano, A. B., Martín, M. A., Bravo, L., Goya, L., \& Ramos, S. (2009). A diet rich in cocoa attenuates $\mathrm{N}$-nitrosodiethylamine-induced liver injury in rats. Food and Chemical Toxicology, 47, 2499-2506. http://doi.org/10.1016/j.fct.2009.07.007

Heckman, M. A, Weil, J., \& Gonzalez de Mejia, E. (2010). Caffeine (1, 3, 7 trimethylxanthine) in foods: a comprehensive review on consumption, functionality, safety, and regulatory matters. Journal of Food Science, 75, R77-87. http://doi.org/10.1111/j.1750- 
Hollebeeck, S., Borlon, F., Schneider, Y. J., Larondelle, Y., \& Rogez, H. (2013). Development of a standardised human in vitro digestion protocol based on macronutrient digestion using response surface methodology. Food Chemistry, 138, 1936-1944. http://doi.org/10.1016/j.foodchem.2012.11.041

Holst, B., \& Williamson, G. (2008). Nutrients and phytochemicals: from bioavailability to bioefficacy beyond antioxidants. Current Opinion in Biotechnology, 19, 73-82. http://doi.org/10.1016/j.copbio.2008.03.003

Huang, D., Ou, B., Hampsch-Woodill, M., Flanagan, J. A., \& Prior, R. L. (2002). Highthroughput assay of oxygen radical absorbance capacity (ORAC) using a multichannel liquid handling system coupled with a microplate fluorescence reader in 96-Well format. Journal of Agricultural and Food Chemistry, 50, 4437-4444. http://doi.org/10.1021/jf0201529

IDF Diabetes Atlas Group. (2015) Update of mortality attributable to diabetes for the IDF Diabetes Atlas: Estimates for the year 2013. Diabetes Research and Clinical Practice. http://dx.doi.org/10.1016/j.diabres.2015.05.03

Kagami, K., Morita, H., Onda, K., Hirano, T., \& Oka, K. (2008). Protective effect of caffeine on streptozotocin-induced beta-cell damage in rats. The Journal of Pharmacy and Pharmacology, 60, 1161-1165. http://doi.org/10.1211/jpp.60.9.0007

Karthikesan, K., Pari, L., \& Menon, V. P. (2010). Protective effect of tetrahydrocurcumin and chlorogenic acid against streptozotocin-nicotinamide generated oxidative stress induced diabetes. Journal of Functional Foods, 2, 134-142. http://doi.org/10.1016/j.jff.2010.04.001

Martínez-López, S., Sarriá, B., Gómez-Juaristi, M., Goya, L., Mateos, R., \& Bravo-Clemente, L. (2014). Theobromine, caffeine, and theophylline metabolites in human plasma and urine after consumption of soluble cocoa products with different methylxanthine contents. Food Research International, 63, 446-455. http://doi.org/10.1016/j.foodres.2014.03.009

Martinez-Saez, N., Ullate, M., Martin-Cabrejas, M. A., Martorell, P., Genovés, S., Ramon, D., \& del Castillo, M. D. (2014). A novel antioxidant beverage for body weight control based on coffee silverskin. Food Chemistry, 150, 227-234. http://doi.org/10.1016/j.foodchem.2013.10.100

Masiello, P., Broca, C., Gross, R., Roye, M., Manteghetti, M., Hillaire-Buys, D., \& Ribes, G. (1998). Experimental NIDDM: development of a new model in adult rats administered streptozotocin and nicotinamide. Diabetes, 47, 224-229.

Mesías, M., Navarro, M., Martinez-Saez, N., Ullate, M., del Castillo, M. D., \& Morales, F. J. (2014). Antiglycative and carbonyl trapping properties of the water soluble fraction of coffee silverskin. Food Research International, 62, 1120-1126. http://doi.org/10.1016/j.foodres.2014.05.058

Monente, C., Ludwig, I. A., Stalmach, A., de Peña, M. P., Cid, C., \& Crozier, A. (2015). In vitro studies on the stability in the proximal gastrointestinal tract and bioaccessibility in Caco-2 cells of chlorogenic acids from spent coffee grounds. International Journal of Food Sciences and Nutrition, 66, 657-664. http://doi.org/10.3109/09637486.2015.1064874

Monteiro, M., Farah, A., Perrone, D., Trugo, L. C., \& Donangelo, C. (2007). Chlorogenic acid 
compounds from coffee are differentially absorbed and metabolized in humans. The Journal of Nutrition, 137, 2196-2201. http://doi.org/137/10/2196.

Mulder, T. P., Rietveld, A. G., \& van Amelsvoort, J. M. (2005). Consumption of both black tea and green tea results in an increase in the excretion of hippuric acid into urine. The American Journal of Clinical Nutrition, 81, 256S-260S.

Murray R L. (1984). Creatinine, In Clinical Chemistry; Theory, Analysis and Correlation,. In L. A. Kaplan, and A. J. Pesce (Eds.), (pp. 1257-1253). St Louis: The C.V. Mosby Company.

Nam, Y. H., Hong, B. N., Rodriguez, I., Ji, M. G., Kim, K., Kim, U.J., \& Kang, T. H. (2015). Synergistic potentials of coffee on injured pancreatic islets and insulin action via KATP channel blocking in zebrafish. Journal of Agricultural and Food Chemistry, 63, 56125621. http://doi.org/10.1021/acs.jafc.5b00027

Nardini, M., Cirillo, E., Natella, F., \& Scaccini, C. (2002). Absorption of phenolic acids in humans after coffee consumption. Journal of Agricultural and Food Chemistry, 50, 57355741. http://doi.org/10.1021/jf0257547

Nowotny, K., Jung, T., Höhn, A., Weber, D., \& Grune, T. (2015). Advanced glycation end products and oxidative stress in type 2 diabetes mellitus. Biomolecules, 5, 194-222. http://doi.org/10.3390/biom5010194

Oki, T., Nagai, S., \& Yoshinaga, M. (2006). Contribution of .BETA.-carotene to radical scavenging capacity varies among orange-fleshed sweet potato cultivars. Food Science and Technology Research, 12, 156-160.

Palafox-Carlos, H., Ayala-Zavala, J. F., \& González-Aguilar, G. A. (2011). The role of dietary fiber in the bioaccessibility and bioavailability of fruit and vegetable antioxidants. Journal of Food Science, 76, R6-R15. http://doi.org/10.1111/j.1750-3841.2010.01957.x

Pellegrini, N., Serafini, M., Colombi, B., Del Rio, D., Salvatore, S., Bianchi, M., \& Brighenti, F. (2003). Total antioxidant capacity of plant foods, beverages and oils consumed in Italy assessed by three different in vitro assays. The Journal of Nutrition, 133, 2812-2819.

Podio, N. S., López-Froilán, R., Ramirez-Moreno, E., Bertrand, L., Baroni, M. V., PérezRodríguez, M. L., Sánchez-Mata, M. C., \& Wunderlin, D. A. (2015). Matching in vitro bioaccessibility of polyphenols and antioxidant capacity of soluble coffee by boosted regression trees. Journal of Aricultural and Food Chemistry, 63, 9572-9582. http://doi: 10.1021/acs.jafc.5b04406

Rice-Evans, C. A., Miller, N. J., \& Paganga, G. (1996). Structure-antioxidant activity relationships of flavonoids and phenolic acids. Free Radical Biology and Medicine, 20, 933-956. http://doi.org/10.1016/0891-5849(95)02227-9

Rodopoulos, N., Wisén, O., \& Norman, A. (1995). Caffeine metabolism in patients with chronic liver disease. Scandinavian Journal of Clinical and Laboratory Investigation, 55, $229-42$.

Rodríguez-Ramiro, I., Martín, M. A., Ramos, S., Bravo, L., \& Goya, L. (2011). Comparative effects of dietary flavanols on antioxidant defences and their response to oxidant-induced stress on Caco2 cells. European Journal of Nutrition, 50, 313-22. http://doi.org/10.1007/s00394-010-0139-2

Shi, X., Dalal, N. S., \& Jain, A. C. (1991). Antioxidant behaviour of caffeine: efficient 

scavenging of hydroxyl radicals. Food and Chemical Toxicology, 29, 1-6.

Singleton, V. L., Orthofer, R., \& Lamuela-Raventós, R. M. (1999). Analysis of total phenols and other oxidation substrates and antioxidants by means of folin-ciocalteu reagent. In I. L. Packer (Ed.), Methods in Enzymology (pp. 152-178). Philadephia. Elsevier. http://doi.org/10.1016/S0076-6879(99)99017-1

Stalmach, A., Williamson, G., \& Crozier, A. (2014). Impact of dose on the bioavailability of coffee chlorogenic acids in humans. Food \& Function, 5, 1727-1737. http://doi.org/10.1039/c4fo00316k

Szkudelski, T. (2001). The mechanism of alloxan and streptozotocin action in B cells of the rat pancreas. Physiological Research / Academia Scientiarum Bohemoslovaca, 50, 537-546.

Uribarri, J., del Castillo, M. D., de la Maza, M. P., Filip, R., Gugliucci, A., Luevano-Contreras, C., \& Garay-Sevilla, M. E. (2015). Dietary advanced glycation end products and their role in health and disease. Advances in Nutrition, 6, 461-473. http://doi.org/10.3945/an.115.008433

Usansky, J. L., Desai, A., \& Tang-Liu, D. (2010). PK functions for Microsoft Excel. Department of Pharmacokinetics and Drug Metabolism, Allergan, Irvine, CA.

Vallejo, F., Gil-Izquierdo, A., Pérez-Vicente, A., \& García-Viguera, C. (2004). In vitro gastrointestinal digestion study of broccoli inflorescence phenolic compounds, glucosinolates, and vitamin C. Journal of Agricultural and Food Chemistry, 52, 135-138. http://doi.org/10.1021/jf0305128 


\section{Figure captions}

702

Figure 1. Kinetics of the urinary excretion of hippuric acid (A), caffeine (B) and paraxanthine (C) after consumption of CSE (2.2 mg caffeine/ $\mathrm{kg}$ body weight, $0.8 \mathrm{mg}$ CGA/ $\mathrm{kg}$ body weight), CGA (1.5 mg/kg body weight) and caffeine ( $5 \mathrm{mg} / \mathrm{kg}$ body weight). Results represent the concentration $(\mu \mathrm{mol} / \mathrm{mmol}$ creatinine) as mean $(n=7) \pm$ SEM. CGA, chlorogenic acid; CSE, coffee silverskin extract.

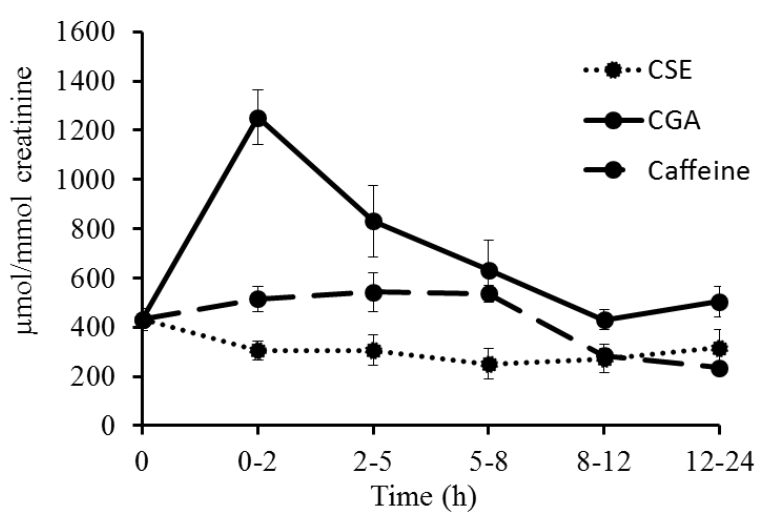

B)

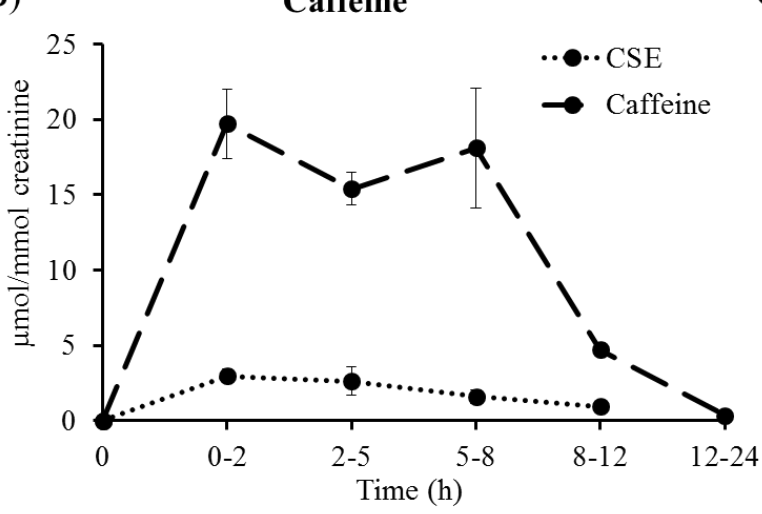

C)

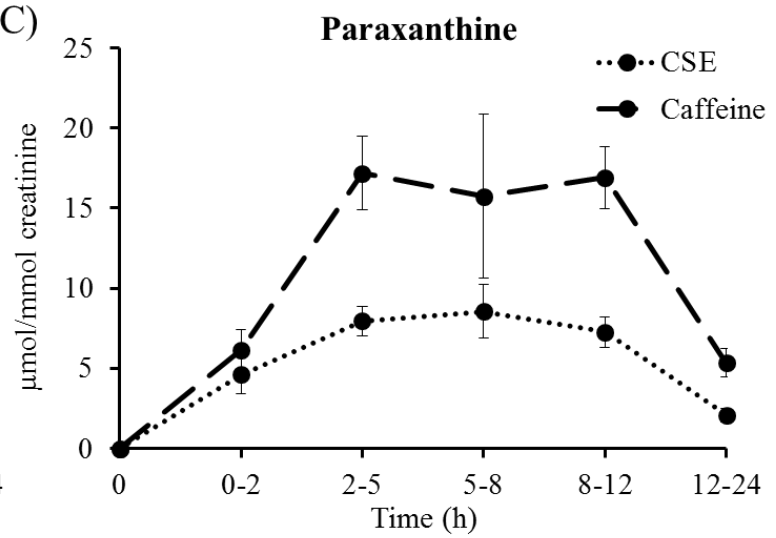

709 
718

719

720

721

722

723

724

725

726

Figure 2. Effect of CSE, CGA and caffeine on oxidative status in pancreatic tissues of STZNA induced diabetic rats. C, untreated healthy control rats; STZ, rats treated with STZ (60 $\mathrm{mg} / \mathrm{kg}$ body weight) and NA (200 mg/kg body weight); CSE, rats treated with STZ-NA and CSE (2.2 mg caffeine/kg body weight, $0.8 \mathrm{mg} \mathrm{CGA} / \mathrm{kg}$ body weight); CGA, rats treated with STZ-NA and $1.5 \mathrm{mg} \mathrm{CGA} / \mathrm{kg}$ body weight; Caffeine, rats treated with STZ-NA and $5 \mathrm{mg}$ caffeine/kg body weight; (A) GSH levels ( $<<0.05$, (B) GR and GPx activities $(\mathrm{p}<0.05)$ and (C) Carbonyl groups production $(p<0.1)$ were evaluated. Data represent means $\pm \operatorname{SEM}(n=8)$.

Different letters denote statistically significant differences referred above in brackets. CGA, chlorogenic acid; CSE, coffee silverskin extract; NA, nicotinamide; STZ, streptozotocin.

A)

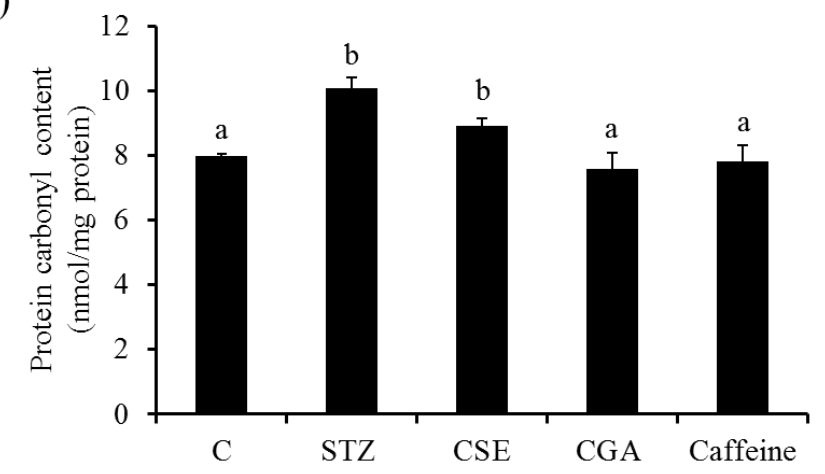

B)

727

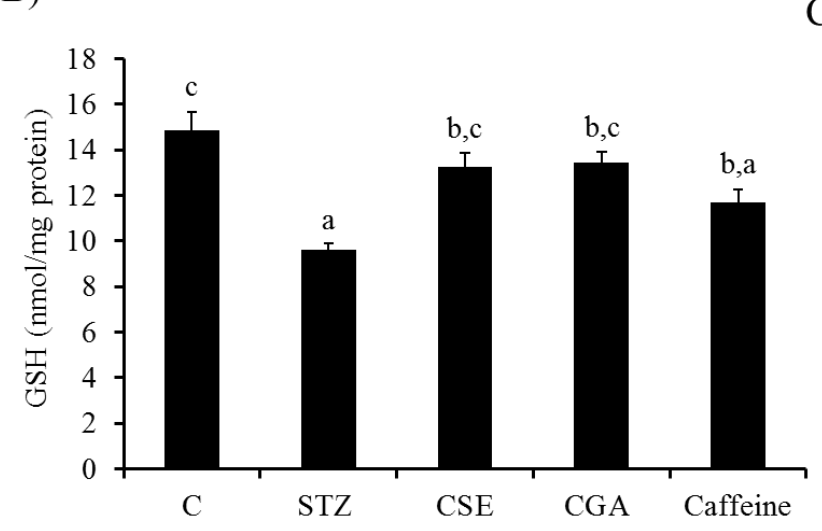

C)

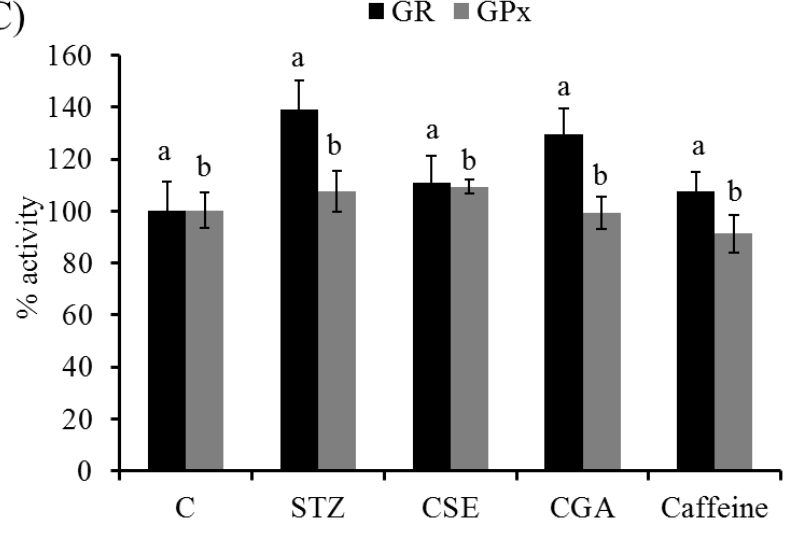


Figure 3. Simplified scheme of CGA and caffeine metabolism studied in the present study.

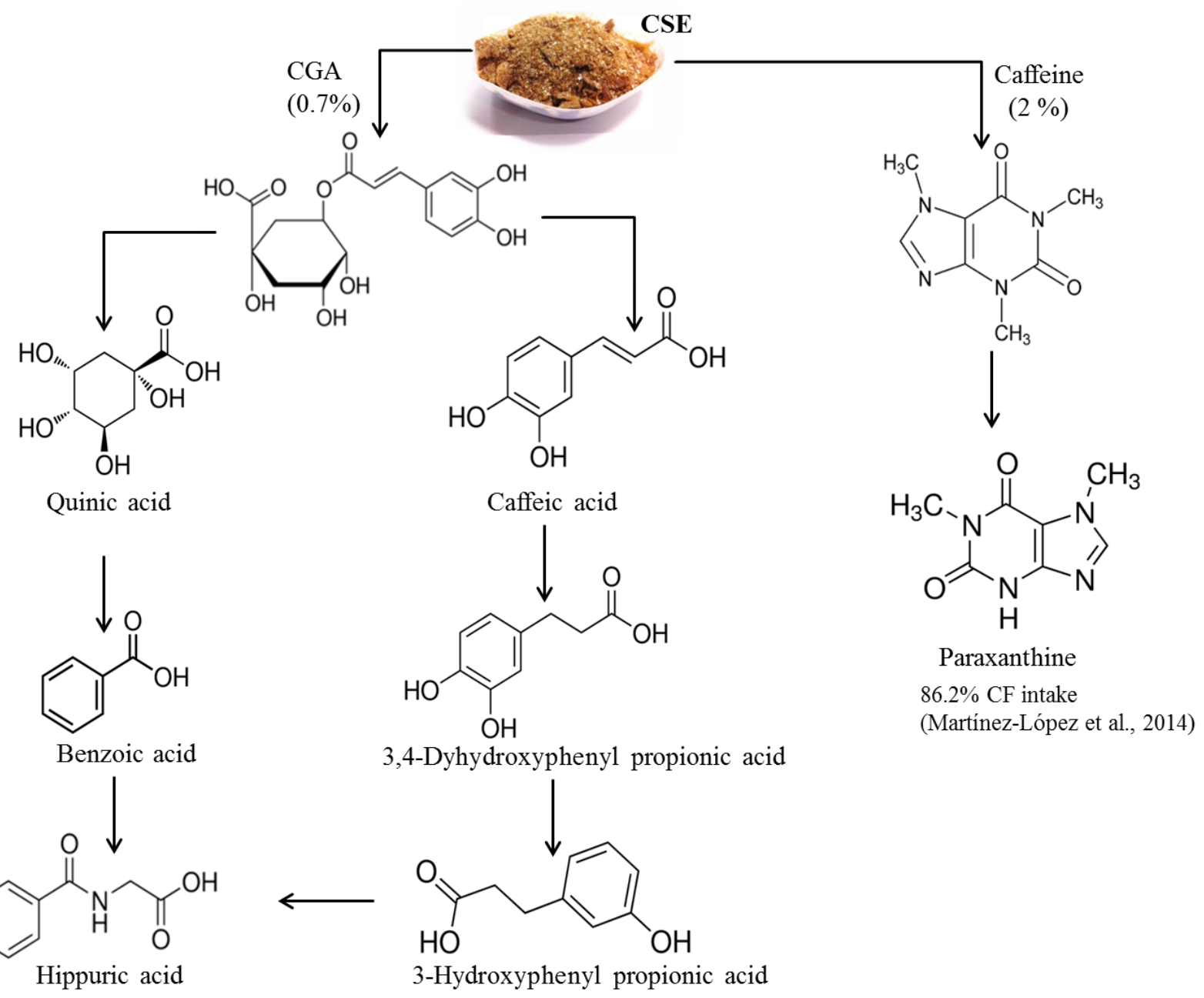


748 Table 1. Antioxidant capacity ( $\mu \mathrm{mol} \mathrm{CGA} / \mathrm{g})$ of non-digested and digested CSE.

749

\begin{tabular}{lcc}
\hline \multicolumn{1}{c}{ Sample } & ABTS & ORAC $_{\text {FL }}$ \\
\hline CSE non-digested & $397 \pm 17^{\mathrm{a}}$ & $358 \pm 25^{\mathrm{a}}$ \\
& & 751 \\
CSE digested & $337 \pm 26^{\mathrm{b}}$ & $179 \pm 13^{\mathrm{b}}$ \\
& & 752 \\
\hline
\end{tabular}

Results are expressed as mean \pm SD for $n=3$. Different letters in the same column indicate significant differenç5 ( $\mathrm{p}$ < 0.05). CGA, chlorogenic acid; CSE, coffee silverskin extract. 
769 Table 2. Pharmacokinetic parameters $\left(\mathrm{C}_{\max }\right.$, AUC and $\left.\mathrm{T}_{\max }\right)$ of metabolites detected in urine 770 after treatments consumption with CSE (2.2 mg caffeine/ $\mathrm{kg}$ body weight, $0.8 \mathrm{mg}$ CGA/ $\mathrm{kg}$ body 771 weight), CGA (1.5 mg CGA/kg body weight); and caffeine (5 mg caffeine/kg body weight).

\begin{tabular}{|c|c|c|c|c|}
\hline Metabolite & Parameters & CSE & CGA & Caffeine \\
\hline & $\begin{array}{c}\mathrm{C}_{\max } \\
(\mathrm{mmol} / \mu \mathrm{mol})\end{array}$ & $447.9 \pm 53.0^{\mathrm{a}}$ & $1346.9 \pm 274.9^{b}$ & $782.6 \pm 104.9^{\mathrm{a}, \mathrm{b}}$ \\
\hline & $\begin{array}{c}\mathrm{T}_{\max } \\
(\mathrm{h})\end{array}$ & $0.8 \pm 0.4^{\mathrm{a}}$ & $1.6 \pm 0.3^{\mathrm{a}}$ & $1.4 \pm 0.4^{\mathrm{a}}$ \\
\hline & $\begin{array}{c}\text { AUC } \\
(\mathrm{mmol} / \mu \mathrm{mol} \cdot \mathrm{h})\end{array}$ & $3727.0 \pm 584.5^{\mathrm{a}}$ & $13842.7 \pm 2182.8^{b}$ & $7369.1 \pm 1171.8^{a}$ \\
\hline & $\begin{array}{c}\mathrm{C}_{\max } \\
(\mathrm{mmol} / \mu \mathrm{mol})\end{array}$ & $3.3 \pm 1.1^{\mathrm{a}}$ & nd & $28.88 \pm 4.6^{b}$ \\
\hline & $\begin{array}{l}\mathrm{T}_{\max } \\
(\mathrm{h})\end{array}$ & $1.8 \pm 0.4^{\mathrm{a}}$ & & $2.50 \pm 0.5^{\mathrm{a}}$ \\
\hline & $\begin{array}{c}\text { AUC } \\
(\mathrm{mmol} / \mu \mathrm{mol} \cdot \mathrm{h})\end{array}$ & $14.8 \pm 5.6^{\mathrm{a}}$ & & $136.66 \pm 17.7^{\mathrm{b}}$ \\
\hline & $\begin{array}{c}\mathrm{C}_{\max } \\
(\mathrm{mmol} / \mu \mathrm{mol})\end{array}$ & $10.7 \pm 2.7^{\mathrm{a}}$ & nd & $22.4 \pm 4.2^{\mathrm{a}}$ \\
\hline & $\begin{array}{l}\mathrm{T}_{\max } \\
(\mathrm{h})\end{array}$ & $5.5 \pm 1.6^{\mathrm{a}}$ & & $4.62 \pm 0.6^{\mathrm{a}}$ \\
\hline & $\begin{array}{c}\text { AUC } \\
(\mathrm{mmol} / \mu \mathrm{mol} \cdot \mathrm{h})\end{array}$ & $125.3 \pm 34.7^{\mathrm{a}}$ & & $265.56 \pm 55.8^{\mathrm{a}}$ \\
\hline
\end{tabular}

772 Values represent mean \pm SEM, $n=7$. Different letters in the same row indicate significant 773 differences between treatments $(p<0.05)$. AUC, area under the curve; $C_{\max }$, maximum 774 concentration reached; CGA, chlorogenic acid; CSE, coffee silverskin extract; n.d., not 775 detected, $\mathrm{T}_{\max }$, time to reach; 